\title{
LIVER TRANSPLANTATION FOR CARCINOMA HEPATOCELLULAR IN SÃO PAULO: 414 CASES BY THE MILAN/ BRAZIL CRITERIA
}

\author{
O transplante hepático por hepatocarcinoma na era MELD em São Paulo: análise de 414 casos transplantados pelo critério de Milão/Brasil
}

Gustavo Pilotto D. SÁ 1 , Fernando P. P. VICENTINEE, ${ }^{1,2}$ Alcides A. SALZEDAS-NETTOO, ${ }^{1,2}$, Carla Adriana Loureiro de MATOS ${ }^{2}$, Luiz R. ROMERO², Dario F. P. TEJADA ${ }^{2}$, Paulo Celso Bosco MASSAROLLO ${ }^{3}$, Gaspar J. LOPES-FILHO ${ }^{1,2}$, Adriano M. GONZALEZ ${ }^{1,2}$

From the ${ }^{1}$ Programa de Pós-Graduação em Ciência Cinúrgica Interdisciplinar, Universidade Federal de São Paulo; ${ }^{2}$ Setor de Transplante Hepático, Disciplina de Gastroenterologia Cirúrgica, Universidade Federal de São Paulo; e ${ }^{3}$ Setor de Transplante Hepático, Departamento de Cirurgia, Faculdade de Medicina, Universidade de São Paulo ('Postgraduation Program in Interdisciplinary Surgical Science, Federal University of São Paulo; ${ }^{2}$ Sector of Liver Transplantation, Discipline of Surgical Gastroenterology, Federal University of São Paulo; and 'Sector of Liver Transplantation, Department of Surgery, Faculty of Medicine, University of São Paulo), São Paulo, SP, Brazil

HEADINGS - Liver transplantation. Hepatocellular carcinoma. MELD.

\section{Correspondence:}

Adriano Miziara Gonzales

E-mail: amgonzalez@uol.com.br

Financial source: none

Conflicts of interest: none

Received for publication: 12/05/2016 Accepted for publication: 16/08/2016

DESCRITORES - Transplante hepático. Hepatocarcinoma. MELD.
ABSTRACT - Background: The criterion of Milan (CM) has been used as standard for indication of liver transplantation (LTx) for hepatocellular carcinoma (HCC) worldwide for nearly 20 years. Several centers have adopted criteria expanded in order to increase the number of patients eligible to liver transplantation, while maintaining good survival rates. In Brazil, since 2006, the criterion of Milan/Brazil $(\mathrm{CMB})$, which disregards nodules $<2 \mathrm{~cm}$, is adopted, including patients with a higher number of small nodules. Aim: To evaluate the outcome of liver transplantation within the CMB. Methods: The medical records of patients with $\mathrm{HCC}$ undergoing liver transplantation in relation to recurrence and survival by comparing CM and CMB, were analyzed. Results: 414 LTx for HCC, the survival at 1 and 5 years was 84.1 and $72.7 \%$. Of these, $7 \%$ reached the CMB through downstaging, with survival at 1 and 5 years of 93.1 and $71.9 \%$. The $\mathrm{CMB}$ patient group that exceeded the $\mathrm{CM}(8.6 \%)$ had a survival rate of $58.1 \%$ at five years. There was no statistical difference in survival between the groups $\mathrm{CM}, \mathrm{CMB}$ and downstaging. Vascular invasion ( $p<0.001)$, higher nodule size $(p=0.001)$ and number of nodules $>2 \mathrm{~cm}(p=0.028)$ were associated with relapse. The age $(p=0.001)$, female $(p<0.001)$, real MELD $(p<0.001)$, vascular invasion $(p=0.045)$ and number of nodes $>2 \mathrm{~cm}(p<0.014)$ were associated with worse survival. Conclusions: CMB increased by $8.6 \%$ indications of liver transplantation, and showed survival rates similar to CM.
RESUMO - Racional: O critério de Milão (CM) vem sendo utilizado como padrão para indicação do transplante hepático $(\mathrm{TxH})$ por hepatocarcinoma $(\mathrm{HCC})$ em todo mundo há quase 20 anos. Diversos centros têm adotado critérios expandidos com intuito de aumentar o número de pacientes candidatos ao transplante, mantendo bons índices de sobrevida. No Brasil, desde 2006, o critério de Milão/Brasil (CMB), que desconsidera nódulos $<2 \mathrm{~cm}$, é adotado, incluindo pacientes com maior número de nódulos pequenos. Objetivo: Avaliar o resultado do transplante hepático dentro do CMB. Métodos: Foram analisados os prontuários dos pacientes com HCC submetidos ao $\mathrm{TxH}$ em relação à recidiva e sobrevida através da comparação entre $\mathrm{CM}$ e CMB. Resultados: Em 414 TxH por HCC, a sobrevida em 1 e 5 anos foi de 84,1 e 72,7\%. Destes, 7\% atingiram o CMB através de downstaging, com sobrevida em 1 e 5 anos de 93,1 e 71,9\%. O grupo de pacientes do $\mathrm{CMB}$ que excederam o $\mathrm{CM}(8,6 \%)$ teve sobrevida de $58,1 \%$ em cinco anos. Não houve diferença estatística na sobrevida entre os grupos $\mathrm{CM}, \mathrm{CMB}$ e downstaging. A invasão vascular ( $p<0,001)$, tamanho do maior nódulo $(p=0,001)$ e número de nódulos $>2 \mathrm{~cm}(p=0,028)$ associaram-se com recidiva. A idade $(p=0,001)$, sexo feminino $(p<0,001)$, MELD real $(p<0,001)$, invasão vascular $(p=0,045)$ e o número de nódulos $>2 \mathrm{~cm}(p<0,014)$ estiveram associados com a piora na sobrevida. Conclusões: O CMB aumentou em $8,6 \%$ as indicações de TxH e apresentou índices de sobrevida semelhantes ao CM.

\section{INTRODUCTION}

T he hepatocellular carcinoma $(\mathrm{HCC})$ is the most common malignancy of the liver and the sixth leading cause of cancer mortality worldwide, with an incidence of 750,000 new cases per year. Liver transplantation (LTx) is currently considered the best treatment for the patient with liver cirrhosis and $\mathrm{HCC}^{2,11,16}$.

The MELD criteria for liver transplant waiting list, adopted in Brazil since 2006, does not cover some serious liver diseases that lead to loss of liver function, such as hepatocellular carcinoma. These cases were classified as special situation and have received extra points, reaching the top of the waiting list for liver transplantation ${ }^{5,12,15,23}$.

With the special situation, patients with HCC began to take the place of patients with the most deteriorated and worse overall condition liver function. The challenge in adopting an extra score is seeking criteria that reduce the chance of being prioritizing patients with advanced $\mathrm{HCC}$, with high risk of recurrence, instead of patients with higher MELD score ${ }^{6,22,24,29}$. 
In 1996, Mazzaferro et al. introduced the Milan criteria (MC). Cirrhotic patients with single nodule up to $5 \mathrm{~cm}$ or up to three nodules being the largest up to $3 \mathrm{~cm}$, with no macrovascular invasion or detectable metastasis had a survival rate of $75 \%$ in four years ${ }^{21}$. The concepts identified in this study have been widely adopted and reproduced in transplant centers in the world, including Brazil, where the good results of survival in this population was reproduced $6,9,14,20,21,24$. However, only a small portion of patients with HCC fit into the MC, stimulating the development of expanded criteria, with satisfactory results ${ }^{28}$.

Thus, other broader criteria began to emerge (Table 1) in order to offer more patients with hepatocellular carcinoma the possibility of liver transplantation, expanding the limits determined by the $\mathrm{MC}^{14,20,21,24}$.

TABLE 1 - Expanded criteria for liver transplantation for HCC

\begin{tabular}{|c|c|c|c|c|}
\hline & $\mathrm{n}$ & Nodule & Size $(\mathrm{cm})$ & Exams \\
\hline Milan (16) & 48 & 1 or $2-3$ & $\begin{array}{c}\leq 5 \text { or } \leq 3 \\
\text { (each) }\end{array}$ & - \\
\hline UCSF (19) & 70 & 1 or $2-3$ & $\begin{array}{c}\leq 6,5 \text { ou } \leq 4,5 \\
\quad(\text { sum } \leq 8)\end{array}$ & - \\
\hline Navarro (20) & 47 & 1 or $2-3$ & $\leq 6$ ou $\leq 5$ & - \\
\hline Kyoto (21) & 125 & $\leq 10$ & $\leq 5$ (each) & PIVKA-" $<400(\mathrm{mU} / \mathrm{mL})$ \\
\hline Asan (22) & 221 & $\leq 6$ & $\leq 5$ (each) & - \\
\hline Edmonton (23) & 52 & - & $\begin{array}{l}\text { Total volume } \\
\leq 115 \mathrm{~cm} 3\end{array}$ & - \\
\hline Valencia (24) & 257 & $\leq 3$ & $\leq 5($ sum $\leq 10)$ & - \\
\hline \multirow{2}{*}{ Hangzhou (25) } & \multirow{2}{*}{195} & \multirow{2}{*}{-} & Total $\leq 8 \mathrm{~cm}$ & - \\
\hline & & & Total $>8 \mathrm{~cm}$ & AFP $\leq 400$, degree $\mathrm{I} / \mathrm{I}(\mathrm{BX})$ \\
\hline $\begin{array}{l}\text { Up - to - seven } \\
(26)\end{array}$ & 1556 & $\leq 7$ & $\leq 7$ (soma) & - \\
\hline \multirow{2}{*}{ Toronto (27) } & \multirow{2}{*}{294} & Milan & Milan & - \\
\hline & & - & - & pathological criteria \\
\hline \multirow{2}{*}{ Milan/Brazil } & \multirow{2}{*}{414} & 1 or $2-3$ & $\leq 5$ or $\leq 3$ (each) & \multirow{2}{*}{-} \\
\hline & & (excluding & g nodules $<2 \mathrm{~cm}$ ) & \\
\hline
\end{tabular}

Some comparative studies have demonstrated the safety of expanded the Milan criteria, to include more patients without increasing the HCC recurrence rate ${ }^{4,22}$. The implantation of $\mathrm{MC}$ in Brazil was followed by minor modifications. Nodules $<2 \mathrm{~cm}$ are not considered, making this a modified MC adopted exclusively in Brazil, called Milan/Brazil Criteria (MBC).

The objective of this study was to evaluate the results of liver transplantation with special situation for HCC using the MBC, after the implementation of MELD criteria.

\section{METHOD}

This study is registered in Brazil Platform and approved as the CEP 81706 of 21/08/2013.

Data were analyzed retrospectively by reviewing the medical records stored in the São Paulo State Transplantation Center of 414 patients undergoing LTx for HCC, conducted between January 2007 and December 2011 in the city of São Paulo.

The groups determined by preoperative imaging (downstaging, $\mathrm{MBC}$ and $\mathrm{MC}$ ) were compared with each other and with respect to the results of survival and recurrence rates. The groups determined by pathology of explanted liver (MBC, CM and Out of Criteria) were compared with each other in relation to survival and recurrence rates.

\section{Statistical analysis}

Data were analyzed descriptively. For categorical variables, absolute and relative frequencies were presented. The numerical variables were presented in summary measures (mean, quartiles, minimum, maximum and standard deviation). The tests included the Chi-Square, Student's t test, MannWhitney, Kruskal-Wallis, the Kappa coefficient and KaplanMeier survival curve. A p value $<0.05$ was considered statistically significant in all cases. Statistical analysis was carried out with SPSS 20.0 and STATA 12.

\section{RESULTS}

There was a predominance of Caucasian patients (80\%), males (79.5\%) with mean age of 56 years. In January 2015, three hundred patients were alive $(72.5 \%)$. If extra points were not used for HCC, the MELD would be 12.6 on average at the time of transplant. In this study, the patients were on the waiting list for LTx for a year on average.

Patients were submitted to different imaging in the preoperative period. Was selected for the analysis the last imaging test performed before transplantation. Computed tomography (58.7\%) was the test of choice in most cases, followed by magnetic resonance imaging (31.9\%) and ultrasonography (9.4\%). These tests were, on average, made four months before the LTX.

All 414 study patients met the BMC based on preoperative imaging. Of these, 54 (7\%) passed before by downstaging (Table 2). Of these, 33 patients (8.6\%) would be out of the MC; however, there is a high correlation between the two criteria according to the Kappa coefficient $(k=0.6-p<0.001)$.

TABLE 2 - Distribution of patients by Milan criteria in accordance with Milan/Brazil criteria

\begin{tabular}{|cccccccc} 
& \multicolumn{4}{c}{ Milan criteria } & \multirow{2}{*}{ Total } \\
\cline { 2 - 6 } & \multicolumn{2}{c}{ No } & \multicolumn{2}{c}{ Yes } & \multicolumn{1}{c}{} \\
\cline { 2 - 7 } & $\mathrm{n}$ & $\%$ & $\mathrm{n}$ & $\%$ & $\mathrm{n}$ & $\%$ \\
\hline Total & 62 & $15,0 \%$ & 352 & $85,0 \%$ & 414 & $100,0 \%$ \\
\hline No & 29 & $100,0 \%$ & 0 & $0,0 \%$ & 29 & $100,0 \%$ \\
\hline Yes & 33 & $8,6 \%$ & 352 & $91,4 \%$ & 385 & $100,0 \%$ \\
\hline
\end{tabular}

Kappa 0,6 - p $<0,00$

The explant were sent to examination and analyzed the size and real number of nodes present in the explanted livers. Regarding pathology of explanted livers, $11.3 \%$ of patients were out of both criteria and $10.4 \%$ were within the MBC but exceeded the MC (Table 3). There was no statistically significant difference regarding the variables mortality and vascular invasion in patients included in the $\mathrm{CMB}$, Milan criteria, or those submitted to downstaging.

In Table 4, patients groups downstaging, Milan/Brazil Criteria and Milan Criteria, so classified by preoperative tests, were compared with the results of the pathology of explanted livers. Patients undergoing downstaging showed nodules larger than those previously classified by the Milan criteria. Patients classified as Criteria Milan/ Brazil had higher total number of nodes compared to the other two groups. 
TABLE 4 - Comparison between the groups formed by preoperative imaging

\begin{tabular}{|c|c|c|c|c|c|c|c|c|}
\hline Criteria (imaging) & Mean & SD & $\mathrm{n}$ & $p$ & $1^{\circ}$ Quartil & Mediana & $\mathrm{n}$ & $p$ \\
\hline Size of the larger nodule* (pathology) & & & & 0,004 & & & & \multirow{4}{*}{0,004} \\
\hline Downstaging & $36,28^{A}$ & 18,82 & 29 & & 23,00 & 35,00 & 29 & \\
\hline $\mathrm{MC}$ & $27,77^{\mathrm{B}}$ & 13,34 & 352 & & 20,00 & 25,00 & 352 & \\
\hline $\mathrm{MBC}$ & $24,72^{B}$ & 9,36 & 33 & & 20,00 & 22,00 & 33 & \\
\hline Nodules >2 cm (pathology) & & & & 0,118 & & & & \multirow{4}{*}{0,118} \\
\hline Downstaging & 1,21 & 0,68 & 29 & & 1,00 & 1,00 & 29 & \\
\hline MC & 0,97 & 0,72 & 352 & & 1,00 & 1,00 & 352 & \\
\hline $\mathrm{MBC}$ & 1,21 & 1,17 & 33 & & 0,50 & 1,00 & 33 & \\
\hline Nodule total number (pathology) & & & & $<0,001$ & & & & \multirow{4}{*}{$<0,001$} \\
\hline Downstaging & 2,38 & 1,52 & 29 & & 1,00 & 2,00 & 29 & \\
\hline MC & $2,03^{B}$ & 1,52 & 352 & & 1,00 & 1,00 & 352 & \\
\hline $\mathrm{MBC}$ & $3,48^{\mathrm{A}}$ & 2,50 & 33 & & 2,00 & 3,00 & 33 & \\
\hline
\end{tabular}

$\mathrm{p}=$ descriptive level of the Kruskal-Wallis test; $(\mathrm{A})$ and $(\mathrm{B})$ show separate averages from Bonferroni-Dunn multiple comparisons; $\mathrm{SD}=\mathrm{standard}$ deviation; ${ }^{m}$ milimeters
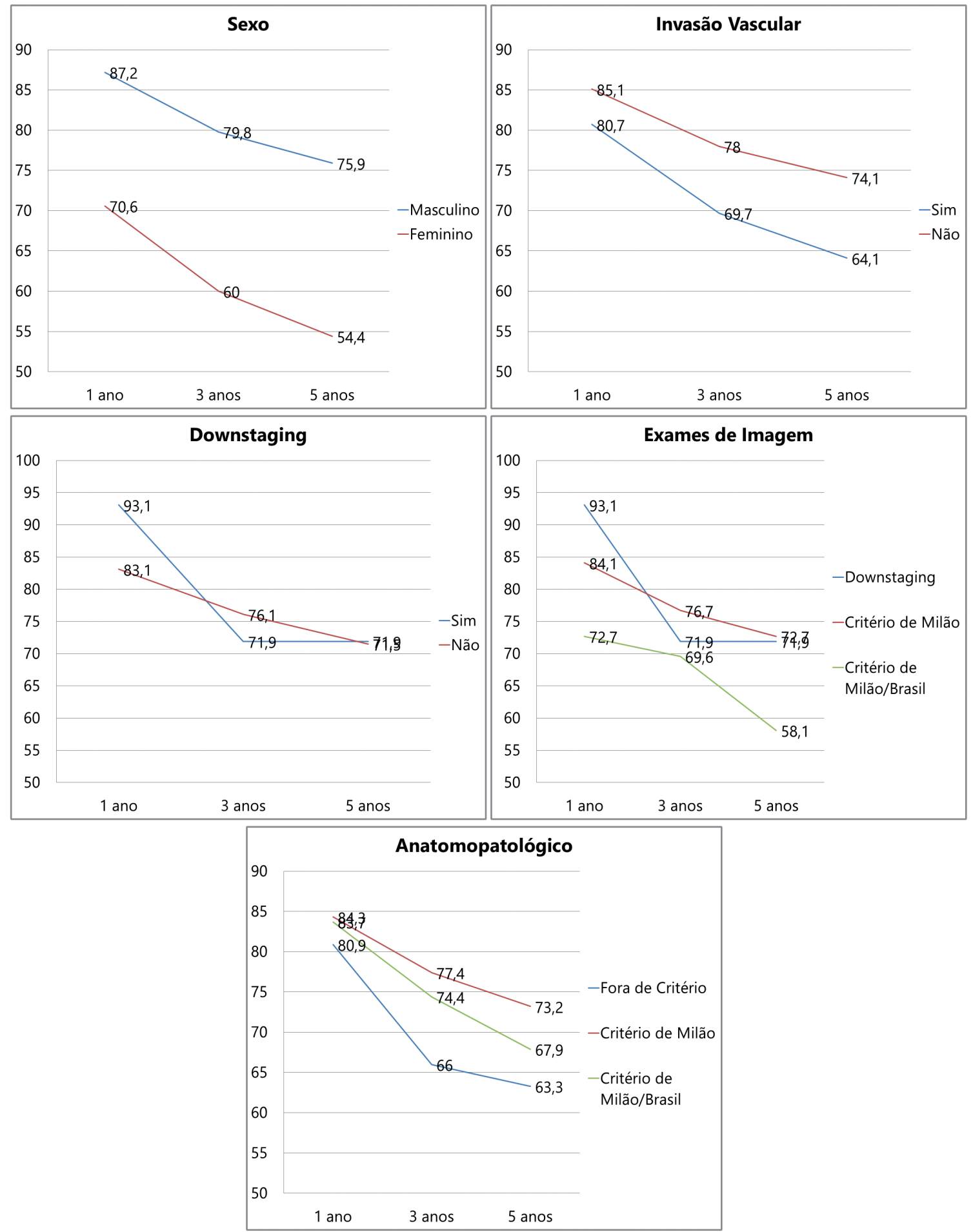

FIGURE 1 - Results of the Kaplan-Meier survival analysis by patient characteristics, imaging and pathology 
TABLE 3 - Distribution of patients by Milan criteria and Milan/ Brazil criteria

\begin{tabular}{|l|c|c|}
\hline Criteria & n & $\%$ \\
\hline Criteria (imaging) & 414 & 100,0 \\
\hline MBC & 33 & 8,0 \\
\hline Downstaging & 29 & 7,0 \\
\hline MC & 352 & 85,0 \\
\hline MBC - (pathology) & 414 & 100,0 \\
\hline No & 47 & 11,3 \\
\hline Yes & 367 & 88,7 \\
\hline MC - (pathology) & 414 & 100,0 \\
\hline No & 103 & 24,9 \\
\hline Yes & 311 & 75,1 \\
\hline
\end{tabular}

$\mathrm{MBC}=$ Milan/Brazil criteria; $\mathrm{MC}=$ Milan criteria

To evaluate the effect of each of the numerical data variables, patient survival were adjusted to a simple Cox regression model (Table 5). There was a correlation between patient age $(p=0.001)$, real MELD $(p<0.001)$, number of nodules $>2 \mathrm{~cm}$ in pathology $(p=0.014)$ and survival time. Thus, every increase of one year in the age of the patient there is an increase of $4.4 \%$ in the risk of death and every 1 -point increase in the real $M E L D$, there is a $5 \%$ increase in the risk of death. Since every increase of 1 nodule $>2 \mathrm{~cm}$ in pathology, there is an increase of $29.2 \%$ in the risk of death.

TABLE 5 - Model results of simple Cox regression with patient data, imaging and pathology in relation to survival

\begin{tabular}{|l|c|c|c|}
\hline & Risk ratio (IC95\%) & p & n \\
\hline Age & $1,044(1,019-1,069)$ & 0,001 & 414 \\
\hline Real MELD & $1,050(1,023-1,078)$ & $<0,001$ & 414 \\
\hline Size of larger nodule (imaging) & $1,003(0,983-1,024)$ & 0,744 & 379 \\
\hline Number of nodule $>2 \mathrm{~cm}$ (imaging) & $1,052(0,657-1,687)$ & 0,832 & 332 \\
\hline Number of nodule $<2 \mathrm{~cm}$ (imaging) & $0,944(0,775-1,150)$ & 0,567 & 413 \\
\hline Nodule total number (imaging) & $1,019(0,841-1,235)$ & 0,848 & 331 \\
\hline Size of larger nodule (pathology) & $1,006(0,994-1,018)$ & 0,326 & 413 \\
\hline Number of nodule $>2 \mathrm{~cm}$ (pathology) & $1,292(1,052-1,586)$ & 0,014 & 414 \\
\hline Number of nodule $<2 \mathrm{~cm}$ (pathology) & $1,035(0,922-1,161)$ & 0,562 & 413 \\
\hline Nodule total number (pathology) & $1,086(0,981-1,203)$ & 0,113 & 413
\end{tabular}

The survival analysis Kaplan-Meier showed significance in relation to gender. Male patients had higher survival than female $(p<0.001)$. The association of increased survival in patients without vascular invasion identified by histopathologic study was demonstrated as well $(p=0.045)$. The other analyzed factors have shown no difference in survival at 1, 3 and 5 years (Figure 1, Table 6).

TABLE 6 - Kaplan-Meier survival analysis for patient data, imaging and pathology

\begin{tabular}{|c|c|c|c|c|}
\hline & \multicolumn{3}{|c|}{ \% Survival (years) } & \multirow[b]{2}{*}{$p$} \\
\hline & 1 & 3 & 5 & \\
\hline Gender & & & & $<0,001$ \\
\hline Female & $70,6 \pm 4,9$ & $60,0 \pm 5,3$ & $54,4 \pm 5,7$ & \\
\hline Male & $87,2 \pm 1,8$ & $79,8 \pm 2,2$ & $75,9 \pm 2,5$ & \\
\hline Vascular Invasion & & & & 0,045 \\
\hline No & $85,1 \pm 2,0$ & $78,0 \pm 2,4$ & $74,3 \pm 2,7$ & \\
\hline Yes & $80,7 \pm 3,8$ & $69,7 \pm 4,4$ & $64,1 \pm 4,7$ & \\
\hline Downstaging & & & & 0,961 \\
\hline No & $83,1 \pm 1,9$ & $76,1 \pm 2,2$ & $71,5 \pm 2,4$ & \\
\hline Yes & $93,1 \pm 4,7$ & $71,9 \pm 8,5$ & $71,9 \pm 8,5$ & \\
\hline Criteria (imaging) & & & & 0,381 \\
\hline $\mathrm{MBC}$ & $72,7 \pm 7,8$ & $69,6 \pm 8,0$ & $58,1 \pm 10,1$ & \\
\hline Downstaging & $93,1 \pm 4,7$ & $71,9 \pm 8,5$ & $71,9 \pm 8,5$ & \\
\hline $\mathrm{MC}$ & $84,1 \pm 1,9$ & $76,7 \pm 2,3$ & $72,7 \pm 2,5$ & \\
\hline Criteria (pathology) & & & & 0,279 \\
\hline Out of Criteria & $80,9 \pm 5,7$ & $66,0 \pm 6,9$ & $63,3 \pm 7,1$ & \\
\hline MBC & $83,7 \pm 5,6$ & $74,4 \pm 6,7$ & $67,9 \pm 7,5$ & \\
\hline $\mathrm{MC}$ & $84,3 \pm 2,0$ & $77,4 \pm 2,3$ & $73,2 \pm 2,6$ & \\
\hline
\end{tabular}

Estimate the probability of survival $\pm S E ; p=$ descriptive level of Log Rank test (Mantel-Cox)
During the study period, were observed (7.2\%) thirty recurrence of $\mathrm{HCC}$ and there was an association only between recurrence and vascular invasion $(p<0.001)$. Thus, it was noted a higher rate of recurrence in patients with vascular invasion (16.5\%) compared to those without this condition (4.0\%). For the other variables, there were no associations (Table 7).

TABLE 7 - Distribution of patients for recurrence and Odds Ratio

\begin{tabular}{|c|c|c|c|c|c|c|c|c|}
\hline & \multicolumn{4}{|c|}{ Recurrence } & \multirow{2}{*}{\multicolumn{2}{|c|}{ Total }} & \multirow{3}{*}{$p$} & \multirow{3}{*}{$\begin{array}{l}\text { Odds } \\
\text { Ratio }\end{array}$} \\
\hline & \multicolumn{2}{|c|}{ No } & \multicolumn{2}{|c|}{ Yes } & & & & \\
\hline & $\mathrm{N}$ & $\%$ & $\mathrm{~N}$ & $\%$ & $\mathrm{~N}$ & $\%$ & & \\
\hline Gender & 384 & $92,8 \%$ & 30 & $7,2 \%$ & 414 & $100,0 \%$ & 0,071 & \\
\hline Female & 75 & $88,2 \%$ & 10 & $11,8 \%$ & 85 & $100,0 \%$ & & 2,06 \\
\hline Male & 309 & $93,9 \%$ & 20 & $6,1 \%$ & 329 & $100,0 \%$ & & 1,00 \\
\hline Vascular Invasion & 381 & $92,7 \%$ & 30 & $7,3 \%$ & 411 & $100,0 \%$ & $<0,001$ & \\
\hline No & 290 & $96,0 \%$ & 12 & $4,0 \%$ & 302 & $100,0 \%$ & & 1,00 \\
\hline Yes & 91 & $83,5 \%$ & 18 & $16,5 \%$ & 109 & $100,0 \%$ & & 4,78 \\
\hline Criteria (imaging) & 384 & $92,8 \%$ & 30 & $7,2 \%$ & 414 & $100,0 \%$ & $0,107^{\mathrm{a}}$ & \\
\hline Downstaging & 24 & $82,8 \%$ & 5 & $17,2 \%$ & 29 & $100,0 \%$ & & 2,98 \\
\hline $\mathrm{MC}$ & 329 & $93,5 \%$ & 23 & $6,5 \%$ & 352 & $100,0 \%$ & & 1,00 \\
\hline $\mathrm{MBC}$ & 31 & $93,9 \%$ & 2 & $6,1 \%$ & 33 & $100,0 \%$ & & 0,92 \\
\hline Criteria (pathology) & 384 & $92,8 \%$ & 30 & $7,2 \%$ & 414 & $100,0 \%$ & $0,139^{a}$ & \\
\hline Out of criteria & 40 & $85,1 \%$ & 7 & $14,9 \%$ & 47 & $100,0 \%$ & & 2,53 \\
\hline $\mathrm{MC}$ & 303 & $93,5 \%$ & 21 & $6,5 \%$ & 324 & $100,0 \%$ & & 1,00 \\
\hline $\mathrm{MBC}$ & 41 & $95,3 \%$ & 2 & $4,7 \%$ & 43 & $100,0 \%$ & & 0,70 \\
\hline
\end{tabular}

$p=$ descriptive level of chi-square test or Fisher's exact test ${ }^{(a)}$

There were significant differences in the variables: larger nodule size $(p=0.005)$, number of nodules $<2 \mathrm{~cm}(p=0.026)$, number of nodes $>2 \mathrm{~cm}(p=0.028)$ and size of the largest nodule $(p=0.001)$ in relation to recurrence rate. Thus, on average, patients with recurrences had higher values in these variables than those without recurrence. Moreover, the average number of lower nodes $2 \mathrm{~cm}$ was lower than in-group of patients with recurrence in the patients without recurrence (Table 8 ).

TABLE 8 - Summary of variable by recurrence occurrence

\begin{tabular}{|c|c|c|c|c|}
\hline HCC Recurrence & Mean & SD & $\mathrm{n}$ & $p$ \\
\hline Age (years) & 56,39 & 8,72 & 414 & 0,052 \\
\hline No & 56,16 & 8,84 & 384 & \\
\hline Yes & 59,37 & 6,40 & 30 & \\
\hline Real MELD & 12,64 & 5,75 & 414 & 0,448 \\
\hline No & 12,56 & 5,60 & 384 & \\
\hline Yes & 13,63 & 7,47 & 30 & \\
\hline Number of nodule $>2 \mathrm{~cm}$ (imaging) & 1,13 & 0,40 & 332 & $0,487^{a}$ \\
\hline No & 1,12 & 0,39 & 306 & \\
\hline Yes & 1,19 & 0,49 & 26 & \\
\hline Size of larger nodule* (imaging) & 27,91 & 9,39 & 379 & $0,005^{\mathrm{a}}$ \\
\hline No & 27,60 & 9,47 & 353 & \\
\hline Yes & 32,04 & 7,19 & 26 & \\
\hline Number of nodule $<2 \mathrm{~cm}$ (imaging) & 0,63 & 0,97 & 413 & 0,026 \\
\hline No & 0,65 & 0,99 & 383 & \\
\hline Yes & 0,37 & 0,61 & 30 & \\
\hline Nodule, total number (imaging) & 1,69 & 1,03 & 331 & $0,784^{a}$ \\
\hline No & 1,69 & 1,05 & 305 & \\
\hline Yes & 1,62 & 0,75 & 26 & \\
\hline Number of nodule $>2 \mathrm{~cm}$ (pathology) & 1,00 & 0,77 & 414 & 0,028 \\
\hline No & 0,98 & 0,77 & 384 & \\
\hline Yes & 1,30 & 0,70 & 30 & \\
\hline Size of larger nodule* (pathology) & 28,13 & 13,71 & 413 & 0,001 \\
\hline No & 27,53 & 13,22 & 383 & \\
\hline Yes & 35,83 & 17,29 & 30 & \\
\hline Number of nodule $<2 \mathrm{~cm}$ (pathology) & 1,17 & 1,53 & 413 & 0,324 \\
\hline No & 1,19 & 1,55 & 384 & \\
\hline Yes & 0,90 & 1,32 & 29 & \\
\hline Nodule, total number (pathology) & 2,17 & 1,66 & 413 & 0,992 \\
\hline No & 2,17 & 1,69 & 384 & \\
\hline Yes & 2,17 & 1,34 & 29 & \\
\hline
\end{tabular}

* = measured in millimeters; $p=$ descriptive level of the Student t test or Mann-Whitney 
DISCUSSION

Most patients were men (79.5\%), white (80\%), middleaged (mean age 56 years), mildly overweight $(\mathrm{BMI}=26.5)$ and low value of MELD (average 12.7). Females in the sample showed a lower survival in Kaplan-Meier curve for 1,3 and 5 years $(p<0.001)$ when compared to males (Table 6 ). This result contradicts what is reported in the medical literature. Duffy et al. demonstrated relative risk of mortality of 2.43 for men $(p<0.023)$; however, this variable was not significant in the multivariate analysis ${ }^{24}$. There is little data available in the literature relating gender as a prognostic factor, but few studies have reported female gender as a protective factor for recurrence and mortality, determining improved survival rate ra,18,19. $^{8}$.

The patient's age is presented as a factor associated with survival $(p=0.001)$. For each increase of one year of age, there is an increase of $4.4 \%$ in the risk of death (Table 5). Other studies have identified age as a prognostic factor of mortality. Adler et al. in the European study for liver transplantation survival, in 226 patients, identified the age of 50 years as a risk factor for increased mortality'.

A few studies have linked real MELD with survival of the transplanted patient, since this value has no influence on the waiting list due to the extra marks for $\mathrm{HCC}^{12,26}$. Todo et al. in Japan, presented a study in patients with HCC underwent living donor liver transplantation demonstrating that the real MELD influenced survival ${ }^{26}$. The results of this study validate the association of real MELD with survival time with $p<0.001$. For each 1 -point increase in the real MELD, there is an increase of $5 \%$ in the risk of death (Table 5).

The waiting time for LTx for HCC patients is crucial for a better prognosis since the progression of the disease can exclude it from the queue for transplantation if nodules size or number exceed the MC. This rate ranges from $7-11 \%$ in 6 months and approaches $40 \%$ at one year ${ }^{30}$.

Some authors, however, suggest that the delay in the waiting list can provide a better selection of candidates for LTx. Patients with aggressive tumor behavior, and increased risk of recurrence present a greater risk of drop out due to faster progression of neoplasia and would not be transplanted ${ }^{25}$. Recent studies have shown increased survival after liver transplantation for HCC in patients who waited longer in the awaiting list ${ }^{14,25}$.

Apparently, patients with HCC have an advantage in the current organ allocation system, when compared with patients without tumor, raising the question of including biological factors of poor prognosis, such as alpha-fetoprotein, and tumor growth rate ${ }^{4}$. Currently, the proportion of transplantation for HCC in São Paulo is around 33\% of total LTx. This scenario is worrying because it coincides with increased mortality in the awaiting list 6,12,22,29.

This analysis shows no association of time on the waiting list and survival. The mean time for the liver transplantation was 11.5 months in patients alive and 13 months in patients who died $(p>0.1)$.

Comparing the $\mathrm{CM}, \mathrm{CMB}$ and downstaging groups, no difference was detected regarding the occurrence of vascular invasion $(p=0.501)$. In accordance with what is widely reported in the literature, vascular invasion showed association with decreased survival. There was a significant difference ( $p$ 0.045), with 5-year survival of $74.3 \%$ for the group without vascular invasion and $64.1 \%$ for the group with vascular invasion. Similarly, the HCC recurrence rate is significantly associated with the presence of vascular invasion detected on pathology $(p<0.001)$.

Following the release of the MC by Mazzaferro et al. in 1996, transplantation in HCC began to show better results, since patients with $\mathrm{HCC}$ to respect the limits of one nodule $\leq 5 \mathrm{~cm}$ or even $3 \mathrm{~cm}$ nodules $\leq 3^{21}$. Most expanded criteria shows increasing the size and number of nodules in a controlled manner would result a recurrence risk and survival rate comparable to the $M^{7,9,14,20,21,24,27}$.

MBC disregards the counting of nodules smaller than $2 \mathrm{~cm}$ and thus offers the possibility of liver transplantation to patients with higher number of small nodules, which would exceed most of the criteria cited above. Table 3 shows the distribution of patients according to $M B C, M C$ and downstaging.

Note that only a small proportion of patients selected for liver transplantation, the CMB has exceeded CM (8.6\%), there is a strong correlation between the two criteria.

Analyzing the groups, the hypothesis that the MBC group has a higher number of nodules on biopsy compared to the $M C$ is confirmed. This significant difference can be explained by the presence of nodules smaller than $2 \mathrm{~cm}$, which are not accounted for at the time of indication for liver transplantation, but are identified on pathology of the explanted liver.

Applying the $\mathrm{MBC}$ and $\mathrm{MB}$ to results from the pathology of explanted livers, the formation of other three groups can be observed, adding to the first two groups the Out of Criteria group (OC, Table 3). This group corresponds to 47 patients (11.3\% of the sample) who did not fulfill neither of the two allocation criteria and therefore configure the failure rate in the Brazilian allocation system. Other studies showed a failure rate that ranged from $18-40 \% \%^{1,4,10}$.

There was no difference in patient survival between the $\mathrm{MBC}$ and $\mathrm{MC}$ groups. Patients transplanted in the MBC had a survival rate of $72.6 \%$ at five years, comparable to the most important services in the world ${ }^{14}$. Considering only those patients who exceeded the MC, the survival rate drops to $58.1 \%$, but without statistical significance. The decrease in survival is probably associated with higher number of identified nodules in the MBC group. Several studies of risk factors for post-LTx mortality from HCC indicate to multiple nodules as a criterion of poor prognosis 2,16,10.

There was no statistical difference in vascular invasion and survival when compared both groups, submitted or not to downstaging, respectively, $71.9 \%$ and $71.5 \%$ survival at five years (Figure 1). This result confirms the data widely available in the literature ${ }^{3,7,13,17}$

The recurrence was associated with the size of the largest nodule, both measured by imaging preoperative $(p=0.005)$ as the pathology of the explanted liver $(p<0.001)$. Patients with larger nodules showed a higher recurrence rate. The number of nodules larger than $2 \mathrm{~cm}$ identified in pathology also been associated with the recurrence of HCC after liver transplantation $(p<0.028)$.

\section{CONCLUSION}

The CMB increased by $8.6 \%$ indications of liver transplantation, and showed survival rates similar to $\mathrm{CM}$.

\section{REFERENCES}

1. Adler M, De Pauw F, Vereerstraeten P, Fancello A, Lerut J, Starkel P, et al. Outcome of patients with hepatocellular carcinoma listed for liver transplantation within the Eurotransplant allocation system. Liver Transplant. 2008;14(4):526-33.

2. Beasley RP, Hwang LY, Lin CC, Chien CS. Hepatocellular carcinoma and hepatitis B virus. A prospective study of 22707 men in Taiwan. Lancet. 1981;2(8256):1129-33.

3. Bhoori S, Sposito C, Germini A, Coppa J, Mazzaferro V. The challenges of liver transplantation for hepatocellular carcinoma on cirrhosis. Transpl Int. 2010 Jul;23(7):712-22. 
4. Bonadio I, Colle I, Geerts A, Smeets P, Berardi G, Praet M, et al. Live transplantationforhepatocellularcarcinoma comparing the Milan, UCSF and Asan criteria: long-term follow-up of a Western single institutional experience. Clin Transplant. 2015 May;29(5):425-33.

5. Brasil. Ministério da Saúde. Secretaria de Assistência à Saúde. Portaria GM n 1160 de 29 de maio de 2006. Diário Oficial da União n 103 Brasília, 31 de maio de 2006. Brasil: Secretaria de Assistência à Saúde. Ministério da Saúde.; 2006.

6. Chaib E, Massad E, Varone BB, Bordini AL, Galvão FHF, Crescenzi A, et al. The Impact of the Introduction of MELD on the Dynamics of the Liver Transplantation Waiting List in São Paulo, Brazil. J Transplant. 2014 Jan;2014:219789.

7. Colecchia A, Schiumerini R, Cucchetti A, Cescon M, Taddia M, Marasco G et al. Prognostic factors for hepatocellular carcinoma recurrence. World J Gastroenterol. 2014;20(20):5935-50.

8. Del Gaudio M, Ercolani G, Ravaioli M, Cescon M, Lauro A, Vivarelli M, et al. Liver transplantation for recurrent hepatocellular carcinoma on cirrhosis after liver resection: University of Bologna experience. Am J Transplant. 2008;8(6):1177-85.

9. DuBay D, Sandroussi C, Sandhu L, Cleary S, Guba M, Cattral MS, et al. Liver transplantation for advanced hepatocellular carcinoma using poor tumor differentiation on biopsy as an exclusion criterion. Ann Surg. 2011;253(1):166-72.

10. Duffy JP, Vardanian A, Benjamin E, Watson M, Farmer DG, Ghobrial RM, et al. Liver Transplantation Criteria For Hepatocellular Carcinoma Should Be Expanded. Ann Surg. 2007;246(3):502-11.

11. Ferlay J, Shin HR, Bray F, Forman D, Mathers C, Parkin DM. Estimates of worldwide burden of cancer in 2008: GLOBOCAN 2008. Int J Cancer. 2010;127(12):2893-917.

12. Freitas ACT, Shiguihara RS, Monteiro RT, Pazeto TL, Coelho JCU. Estudo comparativo em pacientes cirróticos portadores e não portadores de carcinoma hepatocelular submetidos ao transplante hepático: análise do meld, do tempo em lista de espera e da sobrevida. $A B C D$, arq. bras. cir. dig. [Internet]. 2016 Mar [cited 2016 Oct 28] ; 29( 1): 21-25

13. Gordon-Weeks AN, Snaith A, Petrinic T, Friend PJ, Burls A, Silva MA Systematic review of outcome of downstaging hepatocellular cance before liver transplantation in patients outside the Milan criteria. $\mathrm{Br}$ Surg. 2011 Sep;98(9):1201-8.

14. Guerrero-Misas M, Rodríguez-Perálvarez M, De la Mata M. Strategies to improve outcome of patients with hepatocellular carcinoma receiving a liver transplantation. World J Hepatol. 2015 Apr 8;7(4):649.

15. loannou GN, PerkinsJD, CarithersRL. LiverTransplantationforHepatocellular Carcinoma: Impact of the MELD Allocation System and Predictors of Survival. Gastroenterology. 2008;134(5):1342-51.

16. KewMC.EpidemiologyofchronichepatitisBvirusinfection, hepatocellular carcinoma, and hepatitis B virus-induced hepatocellular carcinoma. Pathol Biol (Paris). 2010;58(4):273-7.
17. Lewandowski RJ, Kulik LM, Riaz A, Senthilnathan S, Mulcahy MF, Ryu RK, et al. A comparative analysis of transarterial downstaging for hepatocellularcarcinoma:chemoembolizationversusradioembolization. Am J Transplant. 2009 Aug;9(8):1920-8.

18. Marsh JW, Dvorchik I, Iwatsuki S. Liver transplantation in the treatment of hepatocellular carcinoma. J Hepatobiliary Pancreat Surg. 1998 Apr 8;5(1):24-8.

19. Mazzaferro V, Bhoori S, Sposito C, Bongini M, Langer M, Miceli R, et al. Milan criteria in liver transplantation for hepatocellular carcinoma: an evidence-based analysis of 15 years of experience. Liver Transpl. 2011;17 Suppl 2:S44-57.

20. Mazzaferro V, Llovet JM, Miceli R, Bhoori S, Schiavo M, Mariani L, et al. Predicting survivalafterlivertransplantation in patientswith hepatocellular carcinoma beyond the Milan criteria: a retrospective, exploratoryanalysis. Lancet Oncol. Elsevier Ltd; 2009;10(1):35-43.

21. Mazzaferro V, Regalia E, Doci R, Andreola S, Pulvirenti A, Bozzetti F, et al. Livertransplantationforthetreatmentofsmall hepatocellularcarcinomas in patients with cirrhosis. N Engl J Med. 1996;334(11):693-9.

22. Nacif LS, Andraus W, Martino RB, Santos VR, Pinheiro RS, Haddad LBP et al . Adoption of MELD score increases the number of liver transplant. $A B C D$, arq. bras. cir. dig. [Internet]. 2014 Sep [cited 2016 Oct 28] ; 27( 3 ): 201-203.

23. Roayaie K, Feng S. Allocation policy for hepatocellular carcinoma in the MELDera:Roomforimprovement? LiverTransplant.2007;13(11SUPPL.2).

24. Salvalaggio P, Afonso RC, Pereira LA, Ferraz-Neto B-H. The MELD system and livertransplantwaiting-listmortality in developing countries: lessons learned from São Paulo, Brazil. Einstein (Sao Paulo). 2012:10(3):278-85.

25. Schlansky B, Chen Y, Scott DL, Austin D, Naugler WE. Waiting time predicts survival after liver transplantation for hepatocellular carcinoma: A cohort study in the unos registry. Liver Transpl. 2014;

26. TodoS, Furukawa H. Living Donor Liver Transplantation for Adult Patients With Hepatocellular Carcinoma. Ann Surg. 2004;240(3):451-61.

27. Toso C, Trotter J, Wei A, Bigam DL, Shah S, Lancaster J, et al. Total tumor volume predicts risk of recurrence following liver transplantation in patientswith hepatocellularcarcinoma.LiverTranspl.2008;14(8):1107-15.

28. Ulahannan S V, Duffy AG, McNeel TS, Kish JK, Dickie L a, Rahma OE, et al. Earlier presentation and application of curative treatments in hepatocellular carcinoma. Hepatology. 2014;1227:1-30.

29. Veras FJO, Coelho GR, Feitosa-Neto BA, Cerqueira JBG, Garcia RCFG, Garcia JHP. Combined liver-kidney transplantation: experience at a brazilian university hospital. ABCD, arq. bras. cir. dig. [Internet]. 2014 Mar [cited 2016 Oct 28] ; 27( 1 ): 53-55

30. Yao FY, Bass NM, Nikolai B, Davern TJ, Kerlan R, Wu V, et al. Liver transplantationforhepatocellularcarcinoma:analysisofsurvivalaccording to the intention-to-treat principle and dropout from the waiting list. Liver Transpl. 2002;8(10):873-83. 